\section{Ovarian follicular dynamics in buffaloes during different estrus synchronization protocols}

\author{
Wael M.B. Noseir, ${ }^{1}$ Iman E. El-Bawab, \\ Walid R. Hassan, ${ }^{2}$ Mostafa S. Fadel${ }^{2}$ \\ 1Theriogenology Department, Faculty \\ of Veterinary Medicine, Alexandria \\ University; 2Ultrasonography Unit, \\ Animal Reproduction Research Institute, \\ Giza, Egypt
}

\section{Abstract}

The current study was carried out on 26 normal cycling buffaloes. Animals were divided into 4 groups according to the hormonal treatment regime. Group 1 included 11 buffaloes without hormonal treatment. Group 2: five buffaloes injected with one dose of $25 \mathrm{mg}$ prostaglandin F2alpha (PGF2 $\alpha$ ) after ultrasound diagnosis of a mature corpus luteaum in one ovary. Group 3: five buffaloes injected blindly with two doses of $25 \mathrm{mg}$ PGF2 $\alpha$ 11-days interval. Group 4: five buffaloes treated with ovsynch protocol. The pattern of follicular growth (FG) and the corpus luteum (CL) regression were monitored by transrectal ultrasound scanning. Estradiol $17 \beta$ and progesterone profiles were estimated by radioimmunoassay for all groups. Buffaloes in Group 1 showed two (72.7\%) or three (27.3\%) waveslike patterns of follicular development. The average length of the estrous cycle was $21.75 \pm 0.53$ and $27.0 \pm 0.58$ days in 2- and 3 wave cycle respectively. The duration of the $\mathrm{CL}$ was $16.63 \pm 0.53$ and $22.3 \pm 0.88$ days in 2 - and 3 wave cycles. One buffalo in Group 2 did not respond to injection of a single dose of PGF2 $\alpha$, while the other 4 responded. On the day of injection the diameter of the CL was $1.90 \pm 0.11$ $\mathrm{cm}$ and that of dominant follicle was $0.97 \pm 0.07$ $\mathrm{cm}$. On day 2 after injection the follicle diameter was $1.4 \pm 0.09 \mathrm{~cm}$ and the preovulatory follicle on days $3-4$ was $1.5 \pm 0.03 \mathrm{~cm}$. The regressing CL diameter was $1.3 \pm 0.07 \mathrm{~cm}$ and progesterone level decreased from $6.27 \pm 0.82 \mathrm{ng} / \mathrm{mL}$ on day 0 , to $0.13 \pm 0.06 \mathrm{ng} / \mathrm{mL}$ on days $3-4$ post injection. Estradiol levels were increased from $5.40 \pm 1.2 \mathrm{pg} / \mathrm{mL}$ on day 0 , to $15.09 \pm 1.97 \mathrm{pg} / \mathrm{mL}$ on day 3-4 post injection. After injection of the first dose of $\mathrm{PGF}_{2 \alpha}$, in group 3 the maximum follicle diameter was $1.10 \pm 0.04 \mathrm{~cm}$ on day 6 , then started to regress $(0.60 \pm 0.04 \mathrm{~cm})$ on days 13-17 after injection. In the $2^{\text {nd }}$ wave, the ovulatory follicle showed marked increase from day $2(0.34 \pm 0.01 \mathrm{~cm})$ till days $13-17(1.33 \pm 0.08$ $\mathrm{cm})$. The diameter of CL increased from $1.53 \pm 0.03 \mathrm{~cm}$ on day 0 of treatment to
$1.71 \pm 0.04 \mathrm{~cm}$ on day 7 of treatment. The second dose of $\mathrm{PGF}_{2 \alpha}$ resulted in rapid decrease in the diameter of dominant follicle of the first wave from $0.88 \pm 0.05 \mathrm{~cm}$ on day 11 of treatment to $0.60 \pm 0.04 \mathrm{~cm}$ on days $13-17$ (day of estrus) and rapid increase in the diameter of dominant follicle of the second wave from $0.89 \pm 0.08 \mathrm{~cm}$ on day 11 to $1.33 \pm 0.08 \mathrm{~cm}$ on days 13-17. Injection of the second dose of $\mathrm{PGF}_{2 \alpha}$ on day 11 of treatment caused rapid decline in the progesterone level from $5.62 \pm 0.45 \mathrm{ng} / \mathrm{mL}$ on day 10 , to $1.09 \pm 0.34 \mathrm{ng} / \mathrm{mL}$ on day 12 , and $0.17 \pm 0.05 \mathrm{ng} / \mathrm{mL}$ on days $13-17$. Estradiol levels were $0.76 \pm 0.42,3.97 \pm 1.05$ and $5.59 \pm 1.36 \mathrm{pg} / \mathrm{mL}$ on days 10,12 and days $13-17$. In group 4 , the diameter of the largest follicle of the four ovulated buffaloes after first gonadotropin-releasing hormone administration was $1.24 \pm 0.09 \mathrm{~cm}$, while that of the unovulated buffalo was $0.97 \mathrm{~cm}$. The diameter of the largest follicle of the ovulated buffaloes was $1.03 \pm 0.07$ and $1.32 \pm 0.03 \mathrm{~cm}$ on days 7 and 9 of the treatment. The diameter of the CL was $1.6 \pm 0.05$ and $1.22 \pm 0.07 \mathrm{~cm}$ on days 7 and 9 of the treatment. The mean concentration of progesterone level was $1.89 \pm 0.56 \mathrm{ng} / \mathrm{mL}$ on day 6, $0.27 \pm 0.12 \mathrm{ng} / \mathrm{mL}$ on day 8 and to $0.04 \pm 0.01$ $\mathrm{ng} / \mathrm{mL}$ on day 9 of treatment. The mean concentration of estradiol level was $16.07 \pm 9.29$, $1.11 \pm 0.68$ and $2.41 \pm 0.93 \mathrm{pg} / \mathrm{mL}$ on days 6,8 and 9 of the treatment.

\section{Introduction}

The productivity of female buffaloes is essentially affected by the animal's reproductive efficiency which is, in turn, impaired by the late maturity of females, poor estrus expression, and longer intercalving intervals and reduced ovarian activity during the hot season. 1,2 In addition, due to poor estrus detection (30-40\%), 3 a variable duration of estrus (4-64 h) and the difficulty encountered in predicting the time of ovulation. ${ }^{4}$ In effect, the low reproduction potential of the buffalo has been a major concern for decades, but only in recent years have protocols been developed that are able to control the time of ovulation and thus avoid the need for estrus detection.

Problems related to estrus detection constitute major constraints to increasing reproductive rates in buffalo. This consideration indicated a need for estrus synchronization using timed insemination for implementation of breeding programs in buffaloes. The most common synchronization schemes in buffaloes comprised either premature regression of the corpus luteum (CL) by injection of $\mathrm{PGF}_{2 \alpha}$ (prostaglandin $\mathrm{F}_{2 \alpha}$ ) or its synthetic analogues. ${ }^{5}$ Or prolonging the lifespan of the CL by progesterone, ${ }^{6}$ using different doses of GnRH and GnRH analogues, ${ }^{7}$ or by using Ovsynch
Correspondence: Wael Mohammed Bahgat Noseir, Theriogenology Department, Faculty of Veterinary Medicine, Alexandria University, Edfina, Behaira, P.0. 22758, Egypt.

Tel.Fax: +2.045.2960450.

E-mail:wnoseir@alexu.edu.eg

Key words: buffaloes, follicles, waves, estrus, synchronization.

Contributions: the authors contributed equally.

Received for publication: 19 January 2014.

Revision received: 25 February 2014.

Accepted for publication: 4 March 2014.

This work is licensed under a Creative Commons Attribution NonCommercial 3.0 License (CC BYNC 3.0).

(OCopyright W.M.B. Noseir et al., 2014

Licensee PAGEPress srl, Italy

Veterinary Science Development 2014; 4:5315

doi:10.4081/vsd.2014.5315

protocol. 8 The difficulty with these approaches is the variability in time from AI to ovulation and the low conception rate. ${ }^{9}$

Follicular development in buffalo is characterized by a wave-like pattern. Each wave is characterized by wave emergence, growth, dominance and atresia or ovulation. ${ }^{10}$ Normally, in buffalo-cows, there are one or two non-ovulatory follicular waves followed by an ovulatory wave. 11

A comprehension of the pattern of ovarian follicle recruitment and selection in buffaloes could provide some additional insights, and lead to a better refinement of protocols for estrus synchronization and induction of ovulation in buffaloes. The primary objective of the present study was to elucidate ovarian follicular dynamics and hormonal profiles in normal cycling buffaloes and during different estrus synchronization protocols.

\section{Materials and Methods}

\section{Animals and management}

Twenty six adult buffalo-cows aged from 4-5 years at the experimental farm of the Animal Reproduction Research Institute-Al-Haram, Giza, Egypt, were used in this study. All the animals were apparently clinically normal and had regular estrous cycles. The animals were kept in an open yard system with adequate shade and sun. The averaged daily feeding per head was $5 \mathrm{~kg}$ concentrate mixture (containing 14\% protein, $15 \%$ fibers and $3 \%$ fat), $10 \mathrm{~kg}$ rice straw and $30 \mathrm{~kg}$ barseem during the green season. In dry season, barseem is replaced by 20 $\mathrm{kg}$ darawa. Water and mineral salts licks were 
provided in each yard all the time. The estrous cycle was observed two times to assess the normal estrous behavior and estrous cycle length.

\section{Experimental design and ultra- sonography}

Ultrasonography was performed using a real time B-mode scanner (Vetson color, Kontron, France) equipped with $5 \mathrm{LV}$ linear-array rectal auto adapted frequency transducer (frequency range is 3-7 MHz).

Animals were divided into 4 groups according to the different treatment regimes adapted.

\section{Group I}

Included 11 buffaloes without hormonal treatment for studying the follicular dynamics and hormones profile during estrous cycle. Ultrasonography examination was carried out on buffaloes showing external signs of estrus in order to confirm the daily observation by the detection of the ovulatory follicle of the previous cycle which disappeared on the next day. The day of detection of that ovulatory follicle was considered day 0 of the present cycle. This was followed by daily ultrasonic examination of the ovaries to characterize the pattern of growth and regression of the dominant follicle and CL during complete estrous cycle (the period between 2 standing heats each one was started by the presence of large ovulatory follicle that disappeared on the next day). Blood sampling was carried out every other day during the predicted estrous cycle for estimation of serum progesterone and estradiol $17 \beta$.

\section{Group II}

Included 5 buffaloes injected i.m. with one dose of $25 \mathrm{mg} \mathrm{PGF} 2 \alpha$ (dinoprost tromethamine, Lutalyse $^{\circledR}$, Pharmacia, Belgium) after diagnosis of large sized CL. Ultrasonography examination of the ovaries was carried out to characterize the pattern of growth and regression of the dominant follicle and CL. Blood sampling for progesterone and estradiol $17 \beta$ estimation was carried out on days 0 (day of injection of $\mathrm{PGF}_{2 \alpha}$ ), day 2 and days 3-4 after treatment (day of estrus).

\section{Group III}

Included 5 buffaloes randomly injected i.m. with two doses of $25 \mathrm{mg} \mathrm{PGF}_{2 \alpha}$ with 11 days apart without previous ultrasound examination of the ovaries before treatment. The animals were daily examined by ultrasonography from day 0 of treatment till day 13-17 after treatment (day of estrus) to characterize the pattern of growth and regression of the dominant follicle and CL. The day of 1 st injection of $\mathrm{PGF}_{2 \alpha}$ was considered as day 0 of treatment. The blood sampling was carried out every other day, from the $1^{\text {st }}$ day of treatment till the day of estrus, for estimation of serum progesterone and estradiol $17 \beta$.

\section{Group IV}

Included 5 buffaloes treated with Ovsynch protocol: injected i.m. with $100 \mu \mathrm{g}$ GnRH (Buserelin acetate, Receptal ${ }^{\circledR}$, Intervet,

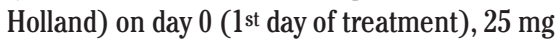
$\mathrm{PGF}_{2 \alpha}$ on day 7 of treatment and $100 \mu \mathrm{g} \mathrm{GnRH}$ on day 9 of treatment according to Paul and Prakash. ${ }^{8}$ Animals were daily examined by ultrasonography from day 0 of treatment till day 10-12 after treatment (day of estrus) to characterize the pattern of growth and regression of the dominant follicle and CL. The day of $1^{\text {st }}$ injection of GnRH was considered as day 0 of treatment. Blood sampling was carried out every other day, from the 1 st day of treatment till the day of estrus, for estimation of serum progesterone and estradiol $17 \beta$.

Collected blood samples were centrifuged immediately at $2500 \mathrm{rpm}$ for $15 \mathrm{~min}$ and serum samples were stored at $-20^{\circ} \mathrm{C}$ until hormone analyses. Determination of serum progesterone and estradiol $17 \beta$ was performed by direct radio immune assay (RIA) using kits from DSL, USA. Data were analyzed by student t-test according to Snedecor and Cochran, by using computer software (costat). ${ }^{12}$

\section{Results}

\section{Group I}

Results obtained from the 1st group (Table 1) revealed that all buffaloes showed either two or three wave pattern of follicular development, no animals showed single wave of follicular development, eight animals (72.7\%) showed 2-wave pattern, while three animals (27.3\%) showed 3wave pattern of follicular development. The average length of the estrous cycle was $21.75 \pm 0.53$ days in 2 -wave cycle and $27.0 \pm 0.58$ days in 3-wave cycle. The duration of the CL in 2 -wave cycles was $16.63 \pm 0.53$ days and $22.3 \pm 0.88$ days in 3 -wave cycles.

\section{Two-wave estrous cycles}

Pattern of development of ovarian follicles and CL was represented in Figure 1A and Table 1. The maximum diameter of the dominant follicle of the 1 st wave was $1.05 \pm 0.04 \mathrm{~cm}$ on day 10 and regressing of this follicle occurred from day 11 of the cycle. The second wave of follicular development started on day 11, and the mean diameter of the ovulatory dominant follicle at time of emergence was $0.38 \pm 0.02 \mathrm{~cm}$. The maximum diameter of the dominant follicle of the $2^{\text {nd }}$ wave was $1.32 \pm 0.02 \mathrm{~cm}$. The maximum diameter of mature CL was $1.63 \pm 0.06$ $\mathrm{cm}$. Progesterone level was on the basal line $(0.16 \pm 0.05$ to $0.29 \pm 0.13 \mathrm{ng} / \mathrm{mL})$ on days $0-2$ of the estrous cycle. The highest concentration of progesterone was recorded on day 14 of the cycle $(3.26 \pm 0.59 \mathrm{ng} / \mathrm{mL})$. From day 15 through day 21 the progesterone level starts to decline to the basal line once again $(0.09 \pm 0.04$ $\mathrm{ng} / \mathrm{mL}$ ). Estradiol level showed maximum concentrations on days $0,2,8,16$ and 21 of the cycle, which were the days of presence of one or more large follicles.

\section{Three-wave estrous cycles}

The 3 -wave cycles were characterized by an obvious increase in the length of the cycle with presence and extended duration of the CL. The dominant follicle of the first wave was observed on day 1 of the cycle with average diameter $0.32 \pm 0.01 \mathrm{~cm}$. The daily increase in the diameter of the dominant follicle of the 1 st wave was observed until day 10 of the cycle with maximum diameter $1.12 \pm 0.03 \mathrm{~cm}$ and regressing of this follicle was observed from day 11 . The dominant follicle of the $2^{\text {nd }}$ wave was observed on day 11 of the cycle with mean diameter $0.35 \pm 0.01 \mathrm{~cm}$. The daily increase in the diameter of the dominant follicle of the $2^{\text {nd }}$ wave was observed until day 20 of the cycle with maximum diameter $0.96 \pm 0.04$. The dominant follicle of the third wave was observed on day 20 of the cycle with mean diameter $0.35 \pm 0.03 \mathrm{~cm}$. The daily increase in the diam-

Table 1. Characteristics of estrous cycle in Buffaloes having 2, 3 follicular waves.

\begin{tabular}{lcc} 
& $\begin{array}{c}\text { 2-wave } \\
(\mathrm{n}=8)\end{array}$ & $\begin{array}{c}\text { 3-wave } \\
(\mathrm{n}=3)\end{array}$ \\
Emergence of 1st wave (day) & $0.75 \pm 0.25$ & $1.00 \pm 0.58$ \\
Emergence of 2nd wave (day) & $11.38 \pm 0.46$ & $11.33 \pm 0.88$ \\
\hline Emergence of 3rd wave (day) & - & $19.67 \pm 0.98$ \\
Persistence of 1st dominant follicle (days) & $18.5 \pm 0.91$ & $15.67 \pm 0.88$ \\
\hline Maximum diameter (cm) & $1.12 \pm 0.04$ & $1.14 \pm 0.03$ \\
Persistence of 2nd dominant follicle (days) & - & $14.33 \pm 0.98$ \\
\hline Maximum diameter (cm) & $10.38 \pm 0.49^{*}$ & $0.99 \pm 0.03$ \\
Persistence of ovulatory dominant follicle (days) & $1.29 \pm 0.04$ & $1.33 \pm 0.87^{*}$ \\
\hline Maximum diameter (cm) & $21.75 \pm 0.53^{*}$ & $27.00 \pm 0.58^{*}$ \\
Duration of interovulatory intervals (days) &
\end{tabular}

Values are means \pm standard error. Values with asterisks in the same raw are significant $(\mathrm{P}<0.01)$. 
eter of the dominant follicle of the 3 rd wave was observed until day 26 of the cycle with maximum diameter $1.23 \pm 0.02 \mathrm{~cm}$. The pattern of growth of these follicles is illustrated in Figure $1 \mathrm{~B}$ and Table 1 . The average duration of CL was 24 days and the average diameter of the mature CL $1.80 \pm 0.02 \mathrm{~cm}$.

Progesterone level was on the basal line $(0.23 \pm 0.01$ to $0.43 \pm 0.02 \mathrm{ng} / \mathrm{mL})$ on days $0-2$ of the estrous cycle. The highest concentration of progesterone was recorded on day 16 of the cycle $(8.56 \pm 0.07 \mathrm{ng} / \mathrm{mL})$. From day 17 through day 26 the progesterone level starts to decline to the basal line once again $(0.09 \pm 0.03$ $\mathrm{ng} / \mathrm{mL}$ ). Estradiol level showed maximum concentrations on days $0,4,6,1825$ and 26 of the cycle, which are the days of presence of one or more large follicles.

\section{Group II}

Out of five treated animals there is only one buffalo-cow that did not respond to injection of a single dose of $\mathrm{PGF}_{2 \alpha}$. Single injection of $\mathrm{PGF}_{2 \alpha}$ in buffaloes having large CL in one of the ovaries produced good results in starting the estrous cycle. On the day of injection the CL was large in size $(1.90 \pm 0.11 \mathrm{~cm})$ and the dominant follicle was $0.97 \pm 0.07 \mathrm{~cm}$ in diameter. On day 2 after injection, an obvious increase in the follicle diameter was recorded $(1.4 \pm 0.09 \mathrm{~cm})$. A preovulatory follicle with a mean diameter of $1.5 \pm 0.03 \mathrm{~cm}$ was recorded on day 3-4 post injection. The regressing CL during these days was $1.3 \pm 0.07 \mathrm{~cm}$ in diameter (Table 2).

Injection of $\mathrm{PGF}_{2 \alpha}$ caused a rapid decline in the progesterone level from $6.27 \pm 0.82 \mathrm{ng} / \mathrm{mL}$ on day 0 , to $0.13 \pm 0.06 \mathrm{ng} / \mathrm{mL}$ on days (3-4) post injection. Estradiol levels were increased from $5.40 \pm 1.2 \mathrm{pg} / \mathrm{mL}$ on day 0 , to $15.09 \pm 1.97 \mathrm{pg} / \mathrm{mL}$ on days 3-4 post injection.

\section{Group III}

After injection of the first dose of $\mathrm{PGF}_{2 \alpha}$, the dominant (anovulatory) follicle of the 1 st wave showed marked increase in diameter from the day of injection to day 6 after injection. The maximum diameter recorded on day 6 was $1.10 \pm 0.04 \mathrm{~cm}$. Then, this follicle started to regress $(0.60 \pm 0.04 \mathrm{~cm})$ on days $13-17$ after injection (Table 3 ). In the $2^{\text {nd }}$ wave, the dominant (ovulatory) follicle showed marked increase from day $2(0.34 \pm 0.01 \mathrm{~cm})$ till day 13 $17(1.33 \pm 0.08 \mathrm{~cm})$. The diameter of $\mathrm{CL}$ increased from $1.53 \pm 0.03 \mathrm{~cm}$ on day 0 of treatment to $1.71 \pm 0.04 \mathrm{~cm}$ on day 7 of treatment.

The second dose of $\mathrm{PGF}_{2 \alpha}$ resulted in rapid decrease in the diameter of dominant follicle of the first wave from $0.88 \pm 0.05 \mathrm{~cm}$ on day 11 of treatment to $0.60 \pm 0.04 \mathrm{~cm}$ on days $13-17$ (day of estrus) and rapid increase in the diameter of dominant follicle of the second wave from $0.89 \pm 0.08 \mathrm{~cm}$ on day 11 of treatment to $1.33 \pm 0.08 \mathrm{~cm}$ on days $13-17$. While, the CL
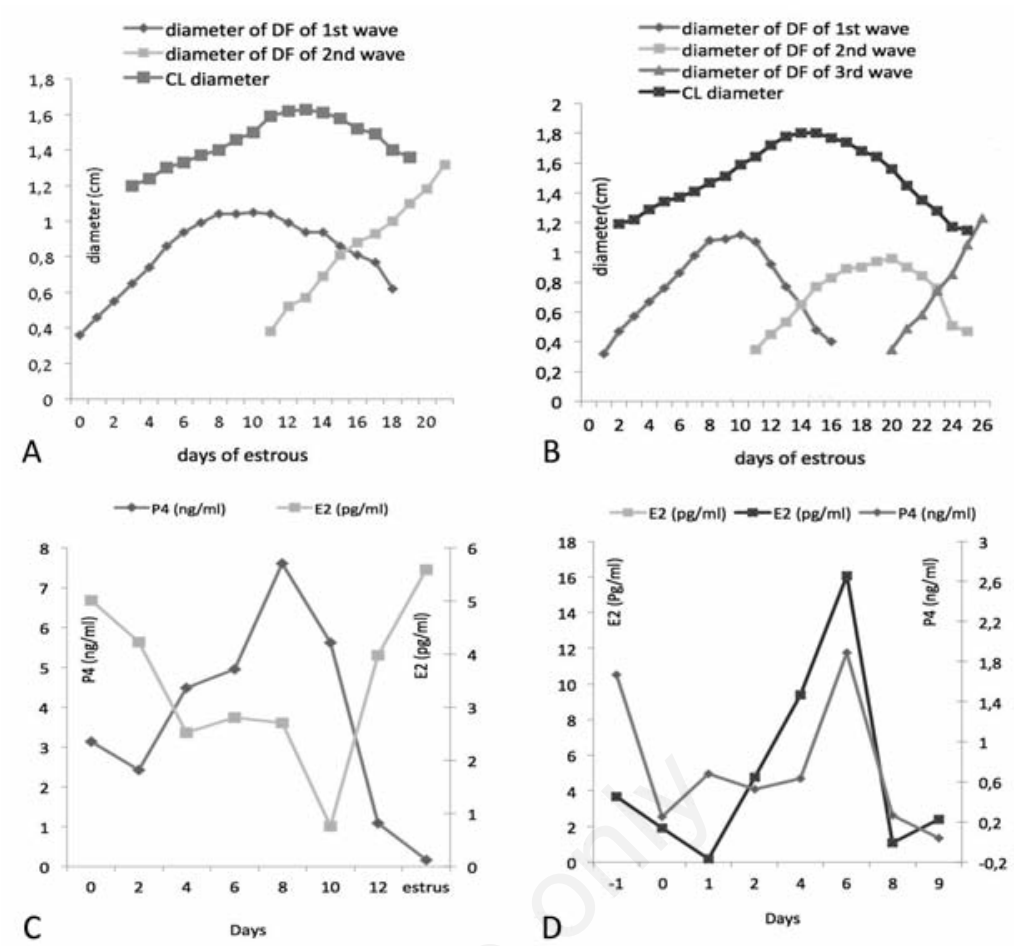

Figure 1. A) mean diameter $( \pm S E)$ of the dominant follicle (DF) in the $1^{\text {st }}, 2^{\text {nd }} 3^{\text {rd }}$ waves and $C L$ diameter in buffaloes having 3 -waves estrous cycles $(n=3) ; B$ ) mean diameter $( \pm S E)$ of the dominant follicle $(D F)$ in the $1^{\text {st }} 2^{\text {nd }}$, waves and $C L$ diameter in buffaloes having 2-wave estrous cycles $(n=8) ; C)$ Pattern of changes in progesterone and estradiol levels during Ovsynch protocol (post 1st GnRH dose) $(n=4)$; D) Pattern of changes in progesterone and estradiol levels in animals treated with double doses of PGF $_{2 \alpha} 11$ days apart $(n=5)$.

Table 2. Mean diameter ( \pm standard error) of ovulatory follicle and CL diameter after treatment with a single dose of PGF2 (Group II, $n=4$ ).

\begin{tabular}{lcc} 
Day & Ovulatory follicle diameter $(\mathrm{cm})$ & CL diameter (cm) \\
Day 0 (day of PGF2 $\alpha$ injection) & $0.97 \pm 0.07$ & $1.9 \pm 0.11$ \\
Day 2 after injection & $1.4 \pm 0.09$ & $1.5 \pm 0.07$ \\
\hline Day of estrus (day 3-4 after injection) & $1.5 \pm 0.03$ & $1.3 \pm 0.07$ \\
\hline
\end{tabular}

Table 3. The mean diameter ( \pm standard error) of anovulatory, ovulatory follicles and CL diameter after treatment of animals using double doses of PGF2 11 days apart (Group III, $n=5$ )

\begin{tabular}{lccc} 
Days & $\begin{array}{c}\text { Diameter of anovulatory } \\
\text { follicle }(\mathrm{cm})\end{array}$ & $\begin{array}{c}\text { Diameter of } \\
\text { ovulatory follicle }(\mathrm{cm})\end{array}$ & $\begin{array}{c}\text { CL diameter } \\
(\mathrm{cm})\end{array}$ \\
Day 0 (1st PGF2 $\alpha$ injection) & $0.9 \pm 0.08$ & - & $1.53 \pm 0.03$ \\
Day 1 & $0.96 \pm 0.07$ & - & $1.53 \pm 0.03$ \\
\hline Day 2 & $1.04 \pm 0.06$ & $0.34 \pm 0.01$ & $1.57 \pm 0.03$ \\
Day 3 & $1.09 \pm 0.04$ & $0.35 \pm 0.06$ & $1.63 \pm 0.03$ \\
\hline Day 4 & $1.10 \pm 0.04$ & $0.39 \pm 0.06$ & $1.65 \pm 0.03$ \\
Day 5 & $1.07 \pm 0.04$ & $0.39 \pm 0.06$ & $1.69 \pm 0.03$ \\
\hline Day 6 & $1.10 \pm 0.04$ & $0.50 \pm 0.04$ & $1.69 \pm 0.04$ \\
Day 7 & $1.04 \pm 0.05$ & $0.53 \pm 0.06$ & $1.71 \pm 0.04$ \\
\hline Day 8 & $0.97 \pm 0.04$ & $0.62 \pm 0.05$ & $1.69 \pm 0.05$ \\
Day 9 & $0.96 \pm 0.04$ & $0.73 \pm 0.08$ & $1.70 \pm 0.06$ \\
\hline Day 10 & $0.91 \pm 0.05$ & $0.83 \pm 0.08$ & $1.67 \pm 0.07$ \\
Day 11 (2nd PGF2 $\alpha$ injection) & $0.88 \pm 0.05$ & $0.89 \pm 0.08$ & $1.60 \pm 0.05$ \\
\hline Day 12 & $0.79 \pm 0.04$ & $1.01 \pm 0.10$ & $1.47 \pm 0.03$ \\
Day 13-17 (day of estrus) & $0.60 \pm 0.04$ & $1.33 \pm 0.08$ & - \\
\hline
\end{tabular}


diameter decreased from $1.60 \pm 0.05 \mathrm{~cm}$ on day 11 of treatment to $1.26 \pm 0.07 \mathrm{~cm}$ on days $13-17$ (Table 3).

Injection of the second dose of $\mathrm{PGF}_{2 \alpha}$ on day 11 of treatment caused rapid decline in the progesterone level from $5.62 \pm 0.45 \mathrm{ng} / \mathrm{mL}$ on day 10 , to $1.09 \pm 0.34 \mathrm{ng} / \mathrm{mL}$ on day 12 , and $0.17 \pm 0.05 \mathrm{ng} / \mathrm{mL}$ on days $13-17$. Estradiol levels increased from $0.76 \pm 0.42 \mathrm{pg} / \mathrm{mL}$ on day 10 , to $3.97 \pm 1.05 \mathrm{pg} / \mathrm{mL}$ on day 12 , and $5.59 \pm 1.36$ $\mathrm{pg} / \mathrm{mL}$ on days 13-17 (Figure 1C).

\section{Group IV}

Out of 5 buffaloes subjected to Ovsynch protocol, four buffaloes showed ovulation after the first dose of GnRH and one buffalo didn't show ovulation. At the beginning of treatment the mean diameter of the largest follicle of the four buffaloes that ovulate after first GnRH administration was $1.24 \pm 0.09 \mathrm{~cm}$, while the diameter of the largest follicle of the animal that did not ovulate after first GnRH administration was $0.97 \mathrm{~cm}$. The first $\mathrm{GnRH}$ was successful in synchronizing a new follicular wave one the day after treatment, and this wave resulted in the development of a new dominant follicle with diameter $0.36 \pm 0.02 \mathrm{~cm}$ in the treated animals. On day 7 of treatment (day of $\mathrm{PGF}_{2 \alpha}$ administration) the mean diameter of the largest follicle of the animals that ovulated after first GnRH administration was $1.03 \pm 0.07 \mathrm{~cm}$. On day 9 of treatment (day of second $\mathrm{GnRH}$ administration) the mean diameter of the largest follicle of the animals that ovulated after first $\mathrm{GnRH}$ administration was $1.32 \pm 0.03$ $\mathrm{cm}$. The mean diameter of CL on day 7 of treatment (day of $\mathrm{PGF}_{2 \alpha}$ administration) was $1.6 \pm 0.05 \mathrm{~cm}$ and then declined to $1.22 \pm 0.07 \mathrm{~cm}$ on day 9 of treatment (day of second GnRH administration). Ovulation occurred 24 hours after the second GnRH injection (Table 4).

The mean concentration of progesterone level (Figure 1D) was $1.89 \pm 0.56 \mathrm{ng} / \mathrm{mL}$ on day 6 of treatment, with $\mathrm{PGF}_{2 \alpha}$ injection on day 7 of treatment the progesterone concentration declined to $0.27 \pm 0.12 \mathrm{ng} / \mathrm{mL}$ on day 8 of treatment and to $0.04 \pm 0.01 \mathrm{ng} / \mathrm{mL}$ on day 9 of treatment (day of the second GnRH injection). While, the mean concentration of estradiol level was $16.07 \pm 9.29 \mathrm{pg} / \mathrm{mL}$ on day 6 of treatment, with $\mathrm{PGF}_{2 \alpha}$ injection on day 7 of treatment the estradiol concentration declined to $1.11 \pm 0.68 \mathrm{pg} / \mathrm{mL}$ on day 8 of treatment and to $2.41 \pm 0.93 \mathrm{pg} / \mathrm{mL}$ on day 9 of treatment.

\section{Discussion}

Daily ultrasonography examination of the ovaries of the cycling buffaloes in the present study indicated the presence of either two $(72.7 \%, \mathrm{n}=8)$ or three $(27.3 \%, \mathrm{n}=3)$ waves of

Table 4. The mean diameter $( \pm S E)$ of follicular development and corpus luteum diameter during Ovsynch protocol in animals that ovulated after $1^{\text {st }} \mathrm{GnRH}$ injection (n=4).

\begin{tabular}{|c|c|c|c|}
\hline Days & $\begin{array}{l}\text { Diameter of ovulatory } \\
\text { follicle after 1st } \\
\text { GnRH injection (cm) }\end{array}$ & $\begin{array}{l}\text { Diameter of ovulatory } \\
\text { follicle after 2nd } \\
\text { GnRH injection (cm) }\end{array}$ & $\begin{array}{l}\text { CL diameter } \\
(\mathrm{cm})\end{array}$ \\
\hline -1 (day before treatment) & $1.20 \pm 0.09$ & - & $1.60 \pm 0.05$ \\
\hline 0 (day of 1st dose of $\mathrm{GnRH}$ ) & $1.24 \pm 0.09$ & - & $1.56 \pm 0.05$ \\
\hline 1 & $1.31 \pm 0.09$ & $0.36 \pm 0.02$ & $1.41 \pm 0.07$ \\
\hline 2 & Ovulation & $0.45 \pm 0.06$ & $1.30 \pm 0.01$ \\
\hline 3 & - & $0.58 \pm 0.06$ & $1.28 \pm 0.02$ \\
\hline 4 & - & $0.70 \pm 0.08$ & $1.40 \pm 0.03$ \\
\hline 5 & - & $0.82 \pm 0.07$ & $1.49 \pm 0.04$ \\
\hline 6 & - & $0.93 \pm 0.07$ & $1.57 \pm 0.07$ \\
\hline 7 (day of PGF2 $\alpha$ injection) & - & $1.03 \pm 0.07$ & $1.60 \pm 0.05$ \\
\hline 8 & - & $1.12 \pm 0.06$ & $1.32 \pm 0.07$ \\
\hline 9 (day of 2 nd dose of $\mathrm{GnRH}$ ) & - & $1.32 \pm 0.01$ & $1.22 \pm 0.03$ \\
\hline
\end{tabular}

follicular growth per the observed cycle that agree with the results obtained by Warriach and Ahmed, ${ }^{13}$ who revealed that $75 \%$ of buffaloes had two waves of follicular activity and only $25 \%$ had three waves during the estrous cycle.

Also, Manik et al. ${ }^{14}$ stated that, in buffaloes, follicular growth during estrous cycle occurred in 2 or 3 waves. While, Taneja et al. ${ }^{15}$ detected the presence of either one $(42.9 \%, \mathrm{n}=3)$ or two waves $(57.1 \%, \mathrm{n}=4)$ of follicular growth per cycle in Indian buffaloes, however they did not record the three wave cycle that might be due to the difference in the breed species. Baruselli et al. ${ }^{16}$ revealed that follicular growth during the estrous cycle occurs in waves; buffaloes showed 1-wave (3.3\%), 2-waves (63.3\%), and 3-waves (33.3\%) of follicular growth. Ginther et al. ${ }^{17}$ found that the factors responsible for having either two or three waves has been described as time of luteal regression, Adams et al. ${ }^{18}$ concluded that circulating $\mathrm{FSH}$; cows with two-wave cycles have two FSH surges and three-wave cycles have three surges, Noseir stated that, in cows, the peaks of FSH were related to lower estrogen concentration, which in turn depended on regression in follicular size. ${ }^{19}$ Genetic predisposition or uncontrolled environmental conditions may play role in regulation of incidence of the 2 or 3 follicular waves within one estrous cycle, and nutrition. ${ }^{20}$ The onset of luteal regression was delayed and consequently the length of estrous cycle was greater in three waves. Warriach and Ahmed have shown that luteal regression began earlier in buffaloes with two waves than those with three waves (16.2 \pm 0.2 days $v s 18.6 \pm 0.6$ days, respectively). ${ }^{13}$ They added that, concentrations of progesterone in serum were higher in buffaloes with three waves during days 14 through 20 compared to buffaloes with two waves of follicular development during the estrous cycle.

In the present study a single injection of
$\mathrm{PGF}_{2 \alpha}$ in buffaloes having large CL in one of the two ovaries and large follicle produces good results in starting the estrous cycle within 72 96 h. Administration of $\mathrm{PGF}_{2 \alpha}$ resulted in decrease of CL diameter and progesterone levels and an increase in the follicle diameter. Only one buffalo-cow out of five treated animals did not respond to injection of single dose of $\mathrm{PGF}_{2 \alpha}$, which could be attributed to the presence of a follicle $(1.17 \mathrm{~cm})$ at late plateau. Brito et al. ${ }^{6}$ stated that in buffalo cows that failed to ovulate after treatment with PGF2 $\alpha$, plasma progesterone concentration decreased in the first $24 \mathrm{~h}$, but did not decline further and was $>1.0 \mathrm{ng} / \mathrm{mL} 48 \mathrm{~h}$ after treatment.

In the present study, injection of double doses of $\mathrm{PGF}_{2 \alpha}$ with 11 days apart resulted in synchronization of estrus in all treated animals $(n=5)$. Warriach and Ahmad revealed that, induced luteolysis on day 9 resulted in ovulation occurred from the dominant follicle of wave 1 in $67 \%$ of buffaloes, and in the remaining $33 \%$, a second dominant follicle ovulated (follicular turnover) during the estrous cycle. ${ }^{13}$ Luteal levels of progesterone promote both the turnover of the dominant follicle and a regular succession of follicular wave in cattle. ${ }^{21}$

In this study, four out of five animals treated with ovsynch protocol showed ovulation after first GnRH administration. At the beginning of treatment the mean diameter of the largest follicle of the animals that ovulate after first $\mathrm{GnRH}$ administration was $>1.00 \mathrm{~cm}$, while the diameter of the largest follicle of the animal that did not ovulate after first GnRH administration was $0.97 \mathrm{~cm}$. Difference in ovulation rates in buffalo after $\mathrm{GnRH}$ injection was attributed to follicle diameter. ${ }^{16}$ Berber et al. ${ }^{22}$ revealed that the mean diameter of the largest follicle $(9.0 \pm 1.7 \mathrm{~mm})$ and the high ovulation rate after first GnRH injection, suggested that the follicles were dominant and functional. In $80 \%$ of treated buffaloes, the injection of $\mathrm{PGF}_{2 \alpha}$ 
resulted in decline in progesterone level to $0.27 \pm 0.12 \mathrm{ng} / \mathrm{mL}$ on day 8 of treatment and to $0.04 \pm 0.01 \mathrm{ng} / \mathrm{mL}$ on day 9 of treatment (day of $2^{\text {nd }} \mathrm{GnRH}$ injection). The decline in plasma progesterone concentrations to basal levels $(\leq 0.4 \mathrm{ng} / \mathrm{mL})$ in response to $\mathrm{PGF}_{2 \alpha}$ treatment confirmed luteolysis at the time of the secondGnRH treatment. ${ }^{8}$

\section{Conclusions}

In conclusion, the present study revealed that follicular development in buffalo occurred in wave like pattern. The 2 -wave estrous cycle was most common (72.7\% vs $27.3 \%)$ than 3 wave cycles. The number of waves in an estrous cycle is associated with length of CL duration on the ovary and with estrous cycle length. Progesterone level affected growth and regression of dominant follicles, that became ovulatory only when progesterone level decreased to $<1 \mathrm{ng} / \mathrm{mL}$. The efficacy of $\mathrm{PGF}_{2 \alpha}$ for causing luteolysis and ovulation was dependent upon progesterone plasma concentration and CL size before treatment. In addition, the interval from treatments to ovulation and the characteristics of the ovulatory follicle were dependent upon follicular status before treatment.

\section{References}

1. Jainudeen MR, Hafez ESE. Cattle and buffalo. In: Hafez ESE, ed. Reproduction in farm animals. 6th ed., Philadelphia: Lea and Febiger; 1993. pp 315-329.

2. Singh J, Nanda AS, Adams GP. The reproductive pattern and efficiency of female buffaloes. Anim Reprod Sci 2000;6061:593-604.

3. Barkawi AK, Bedeir LH, El Wardani MA.
Sexual behaviour of Egyptian buffaloes in post-partum period. Buffalo J 1993;9:22536 .

4. Ohashi OM. Estrus detection in buffalo cow. Buffalo J 1994;10:61-4.

5. Singh 00, Dabas YPS. Synchronization of estrus in Murrah buffaloes with prostaglandin to augment milk production in lean period. Ind J Anim Reprod 1998; 8:93-104.

6. Brito LFC, Satrapa R, Marson EP, Kastelic JP. Efficacy of PGF2alpha to synchronize estrus in water buffalo cows (Bubalus bubalis) is dependent upon plasma progesterone concentration, corpus luteum size and ovarian follicular status before treatment. Anim Reprod Sci 2002;73:23-35.

7. Rastegarnia A, Niasari-Naslaji A, Hovareshti P, et al. The effect of different doses of gonadorelin on ovarian follicle dynamics in river buffalo (Bubalus bubalis). Theriogenology 2004;62:1283-91.

8. Paul V, Prakash, BS. Efficacy of Ovsynch protocol for synchronization of ovulation and fixed-time artificial insemination in Murrah buffaloes (Bubalus bubalis). Theriogenology 2005;64:1049-60.

9. Adams GP. Control of ovarian follicular waves dynamics in cattle. Implications for synchronization and superovulation. Theriogenology 1994;41:19-24.

10. Presicce GA, Senatore EM, Bella A, et al. Ovarian follicular dynamics and hormonal profiles in heifer and mixed-parity Mediterranean Italian buffaloes (Bubalus bubalis) following an estrus synchronization protocol. Theriogenology 2004;61:1343-55.

11. Baruselli PS, Mucciolo RG, Visintin JA, et al. Ovarian follicular dynamics during the estrous cycle in buffalo (Bubalus bubalis). Theriogenology 1997;47:1531-47.

12. Snedecor GW, Cochran WF. Statistical methods. 6th ed. New Delhi: 0xford and IBH publishing Co.; 1967.

13. Warriach HM, Ahmad N. Follicular waves during the oestrous cycle in Nili-Ravi buffaloes undergoing spontenous and PGF $2 \alpha$ induced luteolysis. Anim Reprod Sci 2007;101:332-7.

14. Manik RS, Palta P, Singla SK, Sharma V. Folliculogenesis in buffalo (Bubalus bubalis): a review. Reprod Fertil Dev 2002;14:315-25.

15. Taneja M, Ali A, Singh G. Ovarian follicular dynamics in water buffalo. Theriogenology 1996;46:121-30.

16. Baruselli PS, Madureira EH, Barnabe VH, et al. Follicular dynamics in buffalo submitted to synchronization of ovulation for timed insemination. Arq Fac Vet UFRGS, Porto Alegre. 1999;27:199.

17. Ginther OJ, Knopf L, Kastelic JP. Temporal associations among ovarian events in cattle during estrous cycle with two and three follicular waves. J. Reprod Fertil 1998;87:223-30.

18. Adams GP, Matteri RL, Kastelic JP, et al. Association between surges of follicle stimulating hormone and the emergence of follicular waves in heifers. J Reprod Fertil 1992;94:177-88.

19. Noseir WMB. Ovarian follicular activity and hormonal profile during estrous cycle in cows: the development of 2 versus 3 waves. Reprod Biol Endocrinol 2003;1:50.

20. Murphy MG, Enright WJ, Crowe MA, et al. Effect of dietary intake on pattern of growth of dominant follicles during the estrous cycle in beef heifers. J Reprod Fertil 1991;92:333-8.

21. Sirois J, Fortune JE. Lengthening the bovine estrous cycle with low levels of exogenous progesterone: a model for studying ovarian follicular dominance. Endocrinology 1990;127:916-25.

22. Berber RC, Madureira EH, Baruselli PS. Comparison of two ovsynch protocols (GnRH versus LH) for fixed timed insemination in buffalo (Bubalus bubalis). Theriogenology 2002;57:1421-30. 